\title{
Spiroplasma clarkii sp. nov. from the Green June Beetle (Coleoptera: Scarabaeidae)
}

\author{
R. F. WHITCOMB,$^{1 *}$ J.-C. VIGNAULT, ${ }^{2}$ J. G. TULLY, ${ }^{3}$ D. L. ROSE ${ }^{3}$ P. CARLE, ${ }^{2}$ J. M. BOVÉ,$^{2}$ \\ K. J. HACKETT, ${ }^{1}$ R. B. HENEGAR, ${ }^{1}$ M. KONAI, ${ }^{1}$ AND D. L. WILLIAMSON ${ }^{4}$ \\ Insect Biocontrol Laboratory, Beltsville Agricultural Research Center, Agricultural Research Service, U.S. \\ Department of Agriculture, Beltsville, Maryland 20705'; Laboratoire de Biologie Cellulaire et Moléculaire, \\ Institut Nationale de Recherche Agronomique, 33883 Villenave d'Ornon Cedex, France ${ }^{2}$; Mycoplasma \\ Section, Laboratory of Molecular Microbiology, Frederick Cancer Research Facility, National Institute of \\ Allergy and Infectious Diseases, Frederick, Maryland 21702 ${ }^{3}$; and Department of Anatomical
}

Sciences, State University of New York, Stony Brook, New York $11794^{4}$

\begin{abstract}
Spiroplasma strain $\mathrm{CN}-5^{\mathrm{T}}$ ( $\mathrm{T}=$ type strain), isolated from the gut of the cetoniine scarabaeid beetle Cotinus nitida, was serologically distinct from other spiroplasma species, groups, and subgroups. Cells of strain $\mathrm{CN}-5^{\mathrm{T}}$ were shown by light microscopy to be helical, motile filaments. Cells in early passages exhibited strong translational motility that tended to be lost in later passages. Electron microscopy showed that the cells were bounded by a single cytoplasmic membrane with no evidence of a cell wall. The organism was not susceptible to penicillin. Strain CN-5 ${ }^{\mathrm{T}}$ grew well in SM-1, M1D, and SP-4 liquid media and on solid SP-4 medium under aerobic or anaerobic conditions. The doubling time at $30^{\circ} \mathrm{C}$, the optimum temperature, was $4.3 \mathrm{~h}$. The strain also grew in $1 \%$ serum fraction medium. Strain $\mathrm{CN}-5^{\mathrm{T}}$ produced acid from glucose and catabolized arginine, but did not hydrolyze urea. The guanine-plus-cytosine content of the DNA was $29 \pm 1$ mol\%. The genome size was $1,770 \mathrm{~kb}(1,186 \mathrm{MDa})$. Other uncloned isolates obtained from $C$. nitida or the cetoniine hermit flower beetle Osmoderma eremicola exhibited similar or identical serological patterns. Since no other hosts were discovered in extensive studies, strain $\mathrm{CN}-5^{\mathrm{T}}$ (previously designated group IX) appears to represent a cluster of relatively host-specific cetoniine beetle-associated strains. Strain CN-5 (= ATCC 33827) is designated the type strain of a new species, Spiroplasma clarkii.
\end{abstract}

Some insect species are known for their occurrence at high densities. One of these is the green June beetle, Cotinus nitida, which has been swept by the bushel from the steps of the White House in Washington, D.C. (11). Residents of the Washington, D.C., metropolitan area are familiar with this beetle species, which appears at lights, with loud whirring of wings, on warm evenings in late May or June.

In 1981, T. B. Clark observed these beetles flying over lawns in Beltsville, Md., and at his home in Bowie, Md., where he collected larvae (8) as they consumed dog food on his patio. Clark, as always, curious about the microbial flora of insects, collected a number of adults and larvae and found the guts of many to be infected with spiroplasmas (8). Spiroplasmas did not appear to inhabit other scarabaeid beetles (e.g., the Japanese beetle [Popillia japonica]). Clark found that the green June beetle spiroplasmas were transmitted between beetle life stages $(7,8,17)$. The organisms proved to be readily cultivable and in early passages exhibited strong translational motility, which tended to be lost with successive passages in vitro. Despite this loss of motility, the classical helicity of the organisms was retained through extended passages, so that the representative strain, $\mathrm{CN}-5^{\mathrm{T}}$ ( $\mathrm{T}=$ type strain), is among the most perfectly helical spiroplasmas in culture. Because of its morphological interest and its amenability to laboratory studies, Clark regarded this spiroplasma, classified as group IX (25), as his favorite until his untimely death in 1984.

We report here experimental fulfillment of the proposed steps for designation of a new spiroplasma species and are pleased to name this organism Spiroplasma clarkii for its discoverer.

\footnotetext{
${ }^{*}$ Corresponding author.
}

\section{MATERIALS AND METHODS}

Spiroplasma strains. The techniques used for isolation of spiroplasmas from insects have been described previously (20). Strain CN-5 $-5^{\mathrm{T}}$ was isolated and cultivated by T. B. Clark in 1981 from a triturated suspension of the gut contents of a larval green June beetle $(C$. nitida). Some of the genomic (4) and serologic $(16,25,29)$ features of the organism were reported earlier. Strains OE-1 and OE-2 were isolated by T. B. Clark and R. B. Henegar from the guts of adult hermit flower beetles (Osmoderma eremicola) in 1984 and 1985 (17, 31).

Strain $\mathrm{CN}-5^{\mathrm{T}}$ was purified by standard filtration cloning techniques (22). Representative strains of the 24 recognized groups $(16,25)$ and eight subgroups of spiroplasmas, including type strains of recognized species $(25,31)$, were used for serologic tests.

Culture media and cultivation techniques. Strains $\mathrm{CN}-5^{\mathrm{T}}$, OE-1, and OE-2 were grown in primary cultures in SM-1 liquid medium $(28)$ at $30^{\circ} \mathrm{C}$. After several passages, the isolates were lyophilized. For characterization, the cultures were revived and passaged several times at $30^{\circ} \mathrm{C}$ before cloning. Following cloning, strain $\mathrm{CN}-5^{\mathrm{T}}$ was selected as a representative and was used in subsequent characterization studies. Other culture media used included M1D medium (28), SP-4 medium (28), a conventional mycoplasma medium containing horse serum (12), and serum fraction broth containing $1 \%$ bovine serum fraction (24). Solid formulations of these media were prepared by adding Noble agar (Difco Laboratories, Detroit, Mich.) to final concentrations of 0.8 to $2.25 \%$. Cultures on solid media were incubated at $30^{\circ} \mathrm{C}$, either aerobically with or without supplemental carbon dioxide (GasPak system [BBL Microbiology Systems, Cock- 


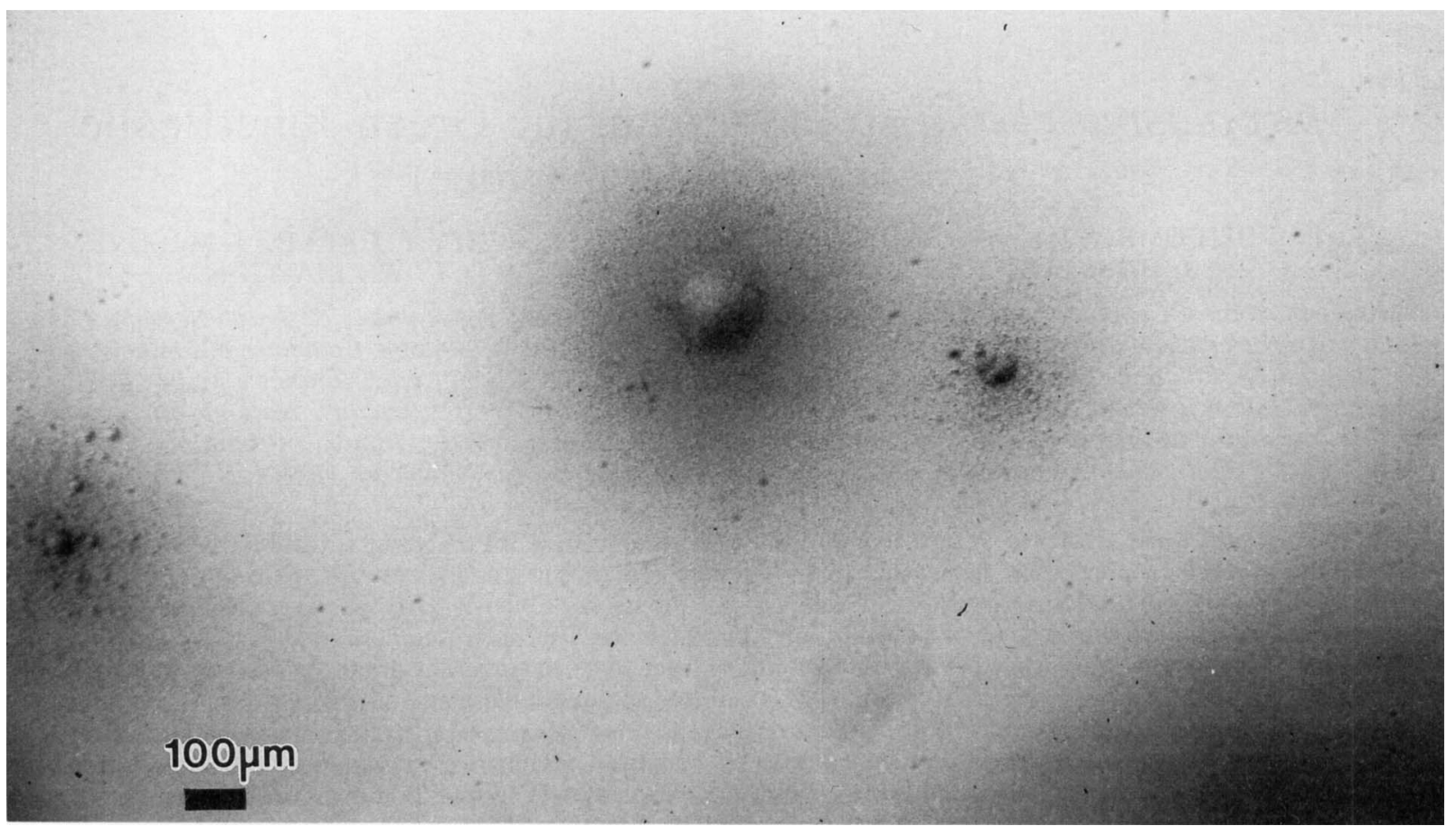

FIG. 1. Colonies of strain $\mathrm{CN}-5^{\mathrm{T}}$ on horse serum agar $\left(0.8 \%\right.$ Noble agar) after 5 days of anaerobic incubation at $30^{\circ} \mathrm{C}$.

eysville, Md.]; $5 \% \mathrm{CO}_{2}$ ) or anaerobically (GasPak system [BBL]; 4 to $7 \% \mathrm{CO}_{2}, 25$ to $35 \% \mathrm{H}_{2},<1 \% \mathrm{O}_{2}$ ).

Temperature requirements for growth were assessed by inoculating strain $\mathrm{CN}-5^{\mathbf{T}}$ into M1D broth. The inoculated cultures were incubated at $5,10,15,20,25,30,32,37$, and $41^{\circ} \mathrm{C}$. Growth was assessed by observing medium indicator change and by microscopic examination of the cultures. Doubling times at each temperature were determined by recording the number of days required for acidification of the growth medium and fitting the data to a logistic growth equation (19).

Morphological studies. Cells of strain $\mathrm{CN}-5^{\mathrm{T}}$ from logarithmic-phase cultures were examined by dark-field microscopy (magnification, $\times 1,250$ ). For electron microscopy, pelleted cells from $20 \mathrm{ml}$ of a culture were fixed for $2 \mathrm{~h}$ in $3 \%$ glutaraldehyde, postfixed in $1 \%$ osmium tetroxide for $1 \mathrm{~h}$, dehydrated in acetone, and embedded in Epon. They were then sectioned and stained with $1 \%$ aqueous uranyl acetate and Reynold's lead citrate.

Sterol requirements. Sterol requirements for growth were determined by a standard broth culture method (23).

Tests for biological and biochemical properties. Carbohydrate fermentation (1), arginine and urea hydrolysis (1), hemadsorption (14), and film and spot reactions (13) were assessed as described earlier. Filtration of logarithmic-phase cultures in M1D broth through pores of different sizes was assessed by techniques reported previously (22).

Serological tests. Antiserum to strain $\mathrm{CN}-5^{\mathrm{T}}$ was produced in rabbits as previously described (33). Antisera to all established Spiroplasma species and groups obtained from reference collections at the Beltsville Agricultural Research Center and the National Institute of Allergy and Infectious Diseases laboratory in Frederick, Md., were used for comparative tests. These reference antisera and strain $\mathrm{CN}-5^{\mathrm{T}}$ were tested in disc growth inhibition $(10,30)$, metabolism inhibition (32), and deformation tests (32).
Genomic analysis. DNA from strain $\mathrm{CN}-5^{\mathrm{T}}$ was extracted and purified as previously described (2). Independent estimates of the guanine-plus-cytosine $(\mathrm{G}+\mathrm{C})$ content of strain $\mathrm{CN}-5^{\mathrm{T}}$ DNA were obtained by buoyant density, melting temperature, and high-performance liquid chromatography techniques (3). The genome size was determined by pulsedfield gel electrophoresis as described by Grau et al. (15).

\section{RESULTS AND DISCUSSION}

Cultural and morphological properties. Strain $\mathrm{CN}-5^{\mathrm{T}}$ grew well in liquid SM-1, M1D, and SP-4 media and on solid media prepared from these formulations. The strain also grew in the Edward formulation of conventional mycoplasma media containing horse serum and in bovine serum fraction medium. Growth of strain $\mathrm{CN}-5^{\mathrm{T}}$ was observed on horse serum agar plates incubated aerobically at $30^{\circ} \mathrm{C}$ or in GasPak systems with 5\% carbon dioxide. Colonies of strain $\mathrm{CN}-5^{\mathrm{T}}$ (Fig. 1) were diffuse, with frequent satellite colonies; fried-egg colonies were never observed. Strain $\mathrm{CN}-5^{\mathrm{T}}$ grew at temperatures ranging from 10 to $32^{\circ} \mathrm{C}$; the strain grew optimally at $30^{\circ} \mathrm{C}$. The doubling times at $10,15,20,25,30$, and $32^{\circ} \mathrm{C}$ were $42.3,20.9,9.2,5.9,4.3$, and $16.7 \mathrm{~h}$, respectively.

Logarithmic-phase cultures of strain $\mathrm{CN}-5^{\mathrm{T}}$, when examined by dark-field microscopy, showed numerous long, helical, motile filaments with six or more turns. Deformed helices were rarely noted. Cells in early passages exhibited strong translational motility. In later passages, this translational motility tended to be lost, although flexional motility was retained. Electron microscopic examinations of cultures revealed filamentous cells delimited by a single membrane (Fig. 2), with no evidence of a cell wall.

Sterol requirement. Strain $\mathrm{CN}-5^{\mathrm{T}}$ failed to grow in SP-4 base broth alone but did grow when 1 to $20 \mu \mathrm{g}$ of cholesterol per $\mathrm{ml}$ was included (Table 1). Similar responses (data not 


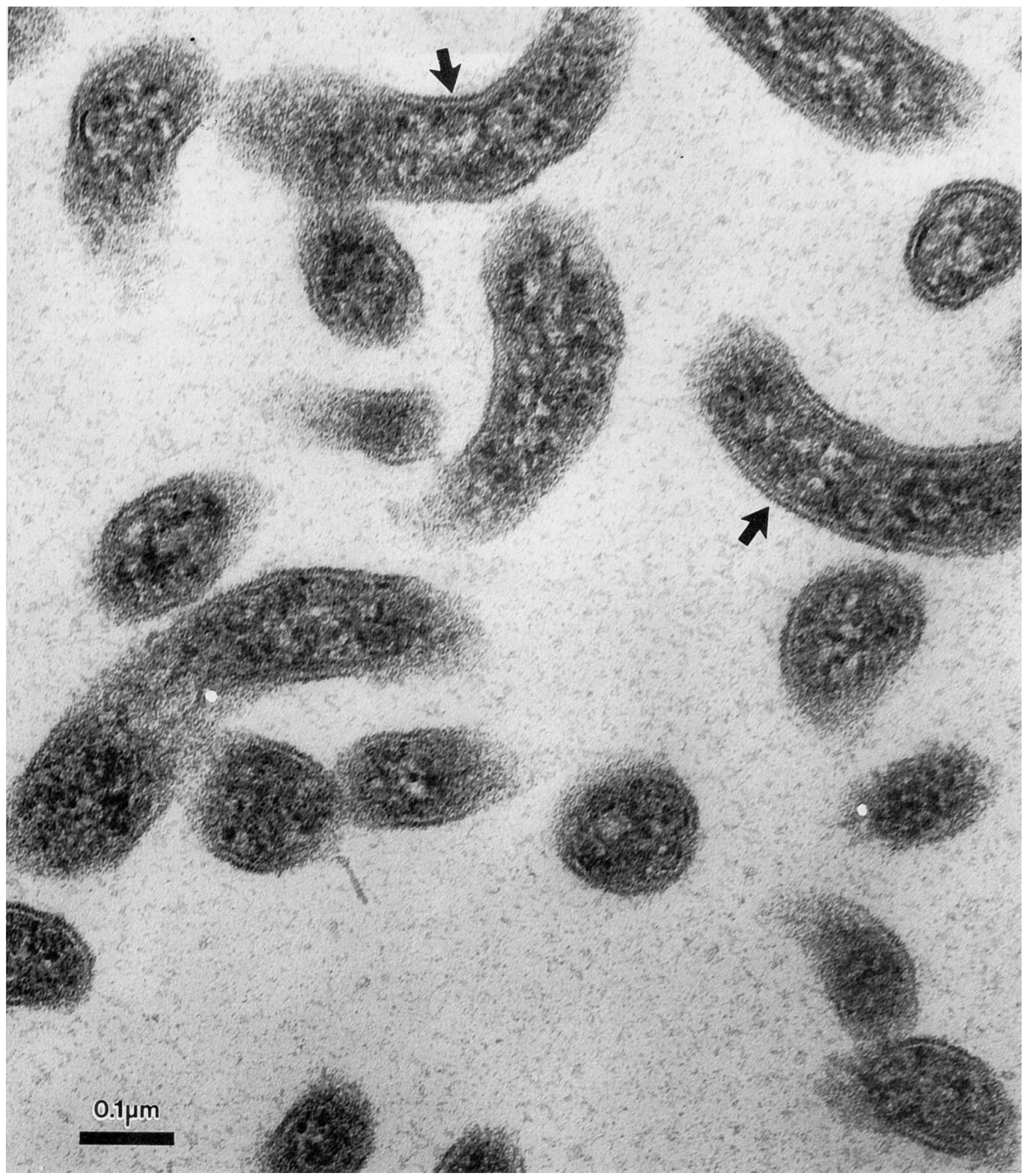

FIG. 2. Electron micrograph of strain $\mathrm{CN}-5^{\mathrm{T}}$. Sections were stained with $2 \%$ aqueous uranyl acetate and Reynold's lead citrate. The arrows indicate the unit membrane.

shown) were observed when the medium was supplemented with fetal bovine serum to achieve a final concentration of 1 to $17 \%$.

Biochemical and biological properties. Strain $\mathrm{CN}-5^{\mathrm{T}}$ fer- mented glucose with production of acid and catabolized arginine, but urea hydrolysis was not observed. Strain $\mathrm{CN}-5^{\mathrm{T}}$ produced the film and spot reaction, but colonies of the organism on an agar medium did not hemadsorb guinea 
TABLE 1. Growth response of strain $\mathrm{CN}-5^{\mathrm{T}}$ to cholesterol

\begin{tabular}{lcc}
\hline \multicolumn{1}{c}{$\begin{array}{c}\text { Supplement(s) added to } \\
\text { serum-free base } \\
\text { medium }\end{array}$} & $\begin{array}{c}\text { Cholesterol } \\
\text { concn } \\
(\mu \mathrm{g} / \mathrm{ml})\end{array}$ & $\begin{array}{c}\text { Amt of protein } \\
(\mathrm{mg} / 100 \mathrm{ml})^{a}\end{array}$ \\
\hline $17 \%$ fetal bovine serum (control) & 0 & 6.825 \\
None & 0 & IG $^{b}$ \\
$1 \%$ albumin, 0.01\% Tween 80, and & 0 & IG \\
$10 \mu \mathrm{g}$ of palmitic acid per ml & 1 & 1.372 \\
& 5 & 4.725 \\
& 10 & 4.000 \\
\hline
\end{tabular}

a Yield for a $100-\mathrm{ml}$ volume of broth. Incubation was at $30^{\circ} \mathrm{C}$ for 4 days.

${ }^{b}$ IG, insufficient growth for detection.

pig erythrocytes. Passage of broth cultures of strain $\mathrm{CN}-5^{\mathrm{T}}$ through 450 - or 300 -nm-pore-size membrane filters did not reduce the viable-cell titer $\left(10^{9}\right.$ color-changing units per $\left.\mathrm{ml}\right)$. The titer of a broth culture filtrate obtained after passage through a 220-nm-pore-size membrane filter was reduced 10 -fold (to $10^{8}$ color-changing units per $\mathrm{ml}$ ); the 100 -nm-poresize membrane filtrate was free of viable cells.

Serological tests. Growth inhibition, metabolism inhibition, and spiroplasma deformation tests demonstrated $(16,25)$ that strain $\mathrm{CN}-5^{\mathrm{T}}$ is serologically unrelated to other spiroplasma groups.

Genomic analysis. The base composition $(\mathrm{G}+\mathrm{C}$ content) of the DNA of $\mathrm{CN}-5^{\mathrm{T}}$ was about $29.0 \pm 1 \mathrm{~mol} \%$, as determined by buoyant density, melting temperature, and high-pressure liquid chromatography methods. The genome size as determined by pulsed-field gel electrophoresis was $1,770 \mathrm{~kb}(1,186$ $\mathrm{MDa}$ ).

Habitat. Strain $\mathrm{CN}-5^{\mathrm{T}}$ and other similar uncloned isolates (CN-1, CN-2, CN-3, CN-7, CN-8, CN-9, CN-10, CN-11, $\mathrm{CN}-12, \mathrm{CN}-13$, and $\mathrm{CN}-14$ from $C$. nitida and $\mathrm{OE}-1$ and OE-2 from $O$. eremicola) were obtained from the guts of scarabaeid beetles. Since extensive studies of other insect taxa failed to reveal other hosts, it is likely that the host range of strain $\mathrm{CN}-5^{\mathrm{T}}$ and its allies is limited and may be confined to beetles, perhaps even cetoniine beetles. A similarly specific host relationship appears to occur with a fastidious spiroplasma that inhabits the gut of the Colorado potato beetle (17).

The ecological interactions of strain $\mathrm{CN}-5^{\mathrm{T}}$ and its allies were studied in some detail by Clark and his associates (8, 17). The organism could be isolated from larvae and adults of the green June beetle, $C$. nitida. Isolation of strains of this cluster from soil in which host larvae had fed suggests that larva-to-larva transmission occurs in the soil. The organism appeared to be relatively host specific, since it did not become established in three other beetle species when it was administered per os. Presence of the spiroplasma in beetle populations appears to be density dependent.

The properties of strain $\mathrm{CN}-5^{\mathrm{T}}$ described here fulfill the proposed criteria (18) for species of the class Mollicutes. Properties mandating assignment to this class include absence of a cell wall, filterability, and penicillin resistance. The requirement of strain $\mathrm{CN}-5^{\mathrm{T}}$ for sterol, its inability to utilize urea, and its helicity and motility place this strain in the family Spiroplasmataceae $(21,26)$. Molecular phylogenetic studies have placed the strain in a cluster of relatively fast-growing, insect-associated Spiroplasma species (27). Previously published serologic comparisons of strain $\mathrm{CN}-5^{\mathrm{T}}$ with representatives of other Spiroplasma species and groups, together with the results described here, establish the position of $\mathrm{CN}-5^{\mathrm{T}}$ and its allies as a distinct Spiroplasma species. Accordingly, we propose the name Spiroplasma clarkii for this organism. This name honors Truman B. Clark, whose extensive studies on spiroplasma ecologyincluding discovery of spiroplasmas in nectar-feeding insects $(5,9)$, on flower surfaces where the insects foraged $(6)$, and in chewing insects (7)-opened the door to an understanding of the main reservoirs of spiroplasmas in nature.

Spiroplasma clarkii sp. nov. Spiroplasma clarkii (clar' ki. i. L. gen. n. clarkii, of Clark, in honor of T. B. Clark, pioneer spiroplasma ecologist). Cells are filamentous, helical, and about $150 \mathrm{~nm}$ in diameter and lack true cell walls. Translational motility in early passages tends to be lost in subsequent passages. Colonies on solid medium supplemented with $0.8 \%$ Noble agar are diffuse, without fried-egg morphology.

Chemoorganotroph. Acid produced from glucose. Catabolizes arginine but does not hydrolyze urea.

Film and spot reaction positive. Does not hemadsorb guinea pig erythrocytes.

Sterol requirement met by cholesterol or serum.

Temperature range, 10 to $32^{\circ} \mathrm{C}$; optimum temperature, $30^{\circ} \mathrm{C}$, with a doubling time of $4.3 \mathrm{~h}$.

Serologically distinct from other established Spiroplasma species and from all described Spiroplasma groups.

Isolated from the gut of a larval scarabaeid beetle $(C$. nitida). Pathogenicity for insects not determined.

The $\mathrm{G}+\mathrm{C}$ content of the DNA is $29 \pm 1 \mathrm{~mol} \%$, as determined by buoyant density, melting temperature, and high-performance liquid chromatography methods. The genome size is $1,770 \mathrm{~kb}(1,186 \mathrm{MDa})$.

The type strain is CN-5 (= ATCC 33827).

\section{ACKNOWLEDGMENTS}

This work was supported in part by Binational Agricultural Research and Development grant US-1902-90R and by U.S. Department of Agriculture Potato Research grants.

\section{REFERENCES}

1. Aluotto, B. B., R. G. Wittler, C. O. Williams, and J. E. Faber. 1970. Standardized bacteriologic techniques for characterization of Mycoplasma species. Int. J. Syst. Bacteriol. 20:35-58.

2. Carle, P., C. Saillard, and J. M. Bové. 1983. DNA extraction and purification. Methods Mycoplasmol. 1:295-299.

3. Carle, P., C. Saillard, and J. M. Bové. 1983. Determination of guanine-plus-cytosine content of DNA. Methods Mycoplasmol. 1:301-308.

4. Carle, P., J. G. Tully, R. F. Whitcomb, and J. M. Bové. 1989. Size of the spiroplasmal genome and guanine-plus-cytosine content of spiroplasmal DNA. Zentralbl. Bakteriol. Suppl. 20:889-892.

5. Clark, T. B. 1977. Spiroplasma sp., a new pathogen in honey bees. J. Invertebr. Pathol. 29:112-113.

6. Clark, T. B. 1978 . Honey bee spiroplasmosis, a new problem for beekeepers. Am. Bee J. 118:18-19, 23.

7. Clark, T. B. 1982. Spiroplasmas: diversity of arthropod reservoirs and host-parasite relationships. Science 217:57-59.

8. Clark, T. B., R. F. Whitcomb, and J. G. Tully. 1982. Spiroplasmas from coleopterous insects: new ecological dimensions. Microb. Ecol. 8:401-409.

9. Clark, T. B., R. F. Whitcomb, J. G. Tully, C. Mouches, C. Saillard, J. M. Bové, H. Wróblewski, P. Carle, D. L. Rose, and D. L. Williamson. 1985. Spiroplasma melliferum sp. nov., a new species from the honeybee (Apis mellifera). Int. J. Syst. Bacteriol. 35:296-308.

10. Clyde, W. A., Jr. 1983. Growth inhibition tests. Methods Mycoplasmol. 1:405-410. 
11. Comstock, J. H. 1949. An introduction to entomology, 9th ed. Comstock Publishing Co., Ithaca, N.Y.

12. Edward, D. G. ff. 1947. A selective medium for pleuropneumonia-like organisms. J. Gen. Microbiol. 1:238-243.

13. Freundt, E. A. 1983. Film and spot production. Methods Mycoplasmol. 1:373-374.

14. Gardella, R. S., and R. A. Del Giudice. 1983. Hemagglutination, hemadsorption, and hemolysis. Methods Mycoplasmol. 1:379384.

15. Grau, O., F. Laigret, P. Carle, J. G. Tully, D. L. Rose, and J. M. Bové. 1991. Identification of a plant-derived mollicute as a strain of an avian pathogen, Mycoplasma iowae, and its implications for mollicute taxonomy. Int. J. Syst. Bacteriol. 41:473-478.

16. Guo, Y. H., T. A. Chen, R. F. Whitcomb, D. L. Rose, J. G. Tully, D. L. Williamson, X. D. Ye, and Y. X. Chen. 1990. Spiroplasma chinensis sp. nov. from flowers of Calystegia hederacea in China. Int. J. Syst. Bacteriol. 40:421-425.

17. Hackett, K. J., and T. B. Clark. 1989. The ecology of spiroplasmas, p. 113-200. In R. F. Whitcomb and J. G. Tully (ed.), The mycoplasmas, vol. 5. Academic Press, Inc., New York.

18. International Committee on Systematic Bacteriology Subcommittee on the Taxonomy of Mollicutes. 1979. Proposál of minimal standards for descriptions of new species of the class Mollicutes. Int. J. Syst. Bacteriol. 29:172-180.

19. Konai, M., E. A. Clark, and R. F. Whitcomb. 1992. Temperature ranges and optima of spiroplasmas. IOM Letters 2:137.

20. Markham, P. G., T. B. Clark, and R. F. Whitcomb. 1983. Culture techniques for spiroplasmas from arthropods. Methods Mycoplasmol. 2:217-223.

21. Skripal, I. G. 1983. Revival of the name Spiroplasmataceae fam. nov., nom. rev., omitted from the 1980 Approved Lists of Bacterial Names. Int. J. Syst. Bacteriol. 33:408.

22. Tully, J. G. 1983. Cloning and filtration techniques for mycoplasmas. Methods Mycoplasmol. 1:173-177.

23. Tully, J. G. 1983. Tests for digitonin sensitivity and sterol requirements. Methods Mycoplasmol. 1:355-362.
24. Tully, J. G. 1984. The family Acholeplasmataceae, p. 775-781. In N. R. Krieg and J. G. Holt (ed.), Bergey's manual of systematic bacteriology, vol. 1. Williams and Wilkins, Baltimore.

25. Tully, J. G., D. L. Rose, E. Clark, P. Carle, J. M. Bové, R. B. Henegar, R. F. Whitcomb, D. E. Colflesh, and D. L. Williamson. 1987. Revised group classification of the genus Spiroplasma (class Mollicutes), with proposed new groups XII to XXIII. Int. J. Syst. Bacteriol. 37:357-364.

26. Tully, J. G., and R. F. Whitcomb. 1991. The genus Spiroplasma, p. 1960-1980. In A. Balows, H. G. Trüper, M. Dworkin, W. Harder, and K. H. Schleifer (ed.), The prokaryotes, vol. 2 (2nd ed.). Springer-Verlag, New York.

27. Weisburg, W. G., J. G. Tully, D. L. Rose, J. P. Petzel, H. Oyaizu, D. Yang, L. Mandelco, J. Sechrest, T. G. Lawrence, J. V. Etten, J. Manilofi, and C. R. Woese. 1989. A phylogenetic analysis of the mycoplasmas: basis for their classification. J. Bacteriol. 171:6455-6467.

28. Whitcomb, R. F. 1983. Culture media for spiroplasmas. Methods Mycoplasmol. 1:147-158.

29. Whitcomb, R. F., T. B. Clark, J. G. Tully, T. A. Chen, and J. M. Bové. 1983. Serological classification of spiroplasmas: current status. Yale J. Biol. Med. 56:453-459.

30. Whitcomb, R. F., J. G. Tully, P. McCawley, and D. L. Rose. 1982. Application of the growth inhibition test to Spiroplasma taxonomy. Int. J. Syst. Bacteriol. 32:387-394.

31. Williamson, D. L., J. G. Tully, and R. F. Whitcomb. 1989. The genus Spiroplasma, p. 71-111. In R. F. Whitcomb and J. G. Tully (ed.), The mycoplasmas, vol. 5. Academic Press, Inc., New York.

32. Williamson, D. L., and R. F. Whitcomb. 1983. Special serological tests for spiroplasma identification. Methods Mycoplasmol. 2:249-259.

33. Williamson, D. L., R. F. Whitcomb, and J. G. Tully. 1978. The spiroplasma deformation test, a new serological method. Curr. Microbiol. 1:203-207. 